\title{
Megalin: a Novel Determinant of Renin-Angiotensin System Activity in the Kidney?
}

\author{
Yuan Sun ${ }^{1,2,3} \cdot$ Xifeng Lu ${ }^{2} \cdot$ A. H. Jan Danser ${ }^{1}$ \\ Published online: 14 March 2020 \\ (C) The Author(s) 2020
}

\begin{abstract}
Purpose of Review Megalin is well known for its role in the reabsorption of proteins from the ultrafiltrate. Recent studies suggest that megalin also reabsorbs renin and angiotensinogen. Indeed, without megalin urinary renin and angiotensinogen levels massively increase, and even prorenin becomes detectable in urine.

Recent Findings Intriguingly, megalin might also contribute to renal angiotensin production, as evidenced from studies in megalin knockout mice. This review discusses these topics critically, concluding that urinary renin-angiotensin system components reflect diminished reabsorption rather than release from renal tissue sites and that alterations in renal renin levels or megalin-dependent signaling need to be ruled out before concluding that angiotensin production at renal tissue sites is truly megalin dependent.

Summary Future studies should evaluate megalin-mediated renin/angiotensinogen transcytosis (allowing interstitial angiotensin generation), and determine whether megalin prefers prorenin over renin, thus explaining why urine normally contains no prorenin.
\end{abstract}

Keywords Megalin · V-ATPase $\cdot$ Chloride channel $\cdot$ Renin $\cdot$ Prorenin $\cdot$ Angiotensinogen $\cdot$ Proteinuria

\section{Introduction}

It is generally believed that renin-angiotensin system (RAS) activity in the kidney is independent of RAS activity in the circulation. Indeed, angiotensin (Ang) II levels in the kidney are several orders of magnitude higher than the levels of Ang II in blood and cannot be explained by uptake from the circulation $[1,2]$. Virtually all renal Ang II is cell associated, either bound to Ang II type $1\left(\mathrm{AT}_{1}\right)$ receptors on the cell surface or

This article is part of the Topical Collection on Hypertension and the Kidney

A. H. Jan Danser

a.danser@erasmusmc.nl

1 Department of Internal Medicine, Division of Pharmacology and Vascular Medicine, Erasmus MC, room EE1418b, Wytemaweg 80, 3015 CN Rotterdam, The Netherlands

2 Department of Physiology, Shenzhen University Health Science Center, Shenzhen University, Shenzhen, China

3 Translational Medicine Collaborative Innovation Center, The Second Clinical Medical College (Shenzhen People's Hospital) of Jinan University, Shenzhen, China present intracellularly [3]. Studies in AT receptor knockout animals revealed that the intracellular presence of Ang II is dependent on $\mathrm{AT}_{1}$ receptor-mediated internalization, i.e., there is no evidence for intracellular Ang II generation [4]. Renal angiotensin generation therefore most likely occurs in the interstitial space. Remarkably, despite evidence for local angiotensinogen synthesis in the kidney, such generation, like circulating angiotensin generation, depends on liver-derived angiotensinogen $[5,6,7 \bullet, 8]$. With an identical substrate source, opposing changes in RAS activity in blood and kidney must be due to other RAS regulatory mechanisms, like the (local) release of renin and its precursor prorenin, the uptake of angiotensinogen from blood (possibly involving more than simple diffusion), and/or local alterations in ACE activity. For instance, in diabetes, the circulating RAS is suppressed, while renal RAS activity is increased [9]. This has been attributed to prorenin synthesis by the principal cells of the collecting duct, evidenced by increased renin activity in the collecting duct and elevated urinary renin levels in this condition [10-12]. However, a recent study in diabetic mice challenged this view and concluded that the increase in collecting duct renin under diabetic conditions reflects renin binding and not local synthesis [13••]. Moreover, the elevated urinary renin levels were 
due to enhanced glomerular filtration of plasma renin in combination with incomplete reabsorption by megalin, i.e., they did not reflect renin release from renal tissue sites (like the collecting duct). Surprisingly, megalin knockout even affected renal angiotensin generation $[14 \bullet \bullet, 15 \bullet$. This review describes the role of megalin as a novel determinant of renal and urinary RAS activity.

\section{What Is Megalin?}

Megalin is a single transmembrane protein consisting of 4655 amino acids with a molecular weight of $600 \mathrm{kDa}$. It has a large extracellular domain, a transmembrane region, and a small intracellular tail of 209 amino acids. It was originally known as glycoprotein 330 [16]. Megalin belongs to the low-density lipoprotein receptor (LDLR) superfamily [17] and contains four regions that consist of cysteine-rich complement-type repeats, four regions that consist of growth factor repeats spaced by eight YWTD repeats, and a single epidermal growth factor (EGF)-like repeat in its extracellular juxtamembrane region. The regions containing complement-type repeats are believed to be important for ligand binding, while the regions containing growth factor repeats are likely required for $\mathrm{pH}$-dependent ligand dissociation in the endosomal compartment $[18,19]$. The overall structure of megalin resembles LDLR-related protein 1 (LRP1), and therefore, megalin is also known as LRP2 [17]. The very large extracellular domain allows megalin to bind multiple ligands [20], and until now, $>50$ ligands for megalin have been described, including albumin, insulin, insulin-like growth factor, lipoproteins, and drugs like aprotinin and polymyxin B [18, 21, 22].

Although megalin was initially identified as an antigen in glomerular podocytes, the expression of megalin in the glomerulus is negligible versus that in the proximal tubule $[16$, 18, 23-26]. Outside the kidney, megalin is also observed in absorptive epithelia in the lung, eye, gall bladder, placenta, and the (para)thyroid gland [18].

Megalin forms a 1:1 complex with the extracellular protein cubilin on the apical plasma membrane of proximal tubule cells, and together, they mediate the endocytosis of ultrafiltrate proteins for subsequent lysosomal degradation and retrieval of their ligands and constituent amino acids into the blood. This prevents massive protein loss via urine. Megalin is a fastrecycling receptor with a long half-life, thereby making it ideal for reabsorption. Its endocytosis depends on the enzymatic activity of an inositol 5-phosphatase encoded by the gene oculocerebrorenal syndrome protein 1 (OCRL1) [27] (Fig. 1). The cytosolic tail of megalin is important for recycling and degradation [28]. Among others, it binds the small GTPase Rab11, and dominant negative mutations in Rab11 result in diminished apical delivery of megalin due to disturbed recycling [29]. Autosomal recessive hypercholesterolemia
(ARH), an adaptor protein that binds megalin in a similar manner as the LDLR and clathrin, retains megalin in the recycling endosomes, so that it cannot reappear on the cell surface [30]. Furthermore, phosphorylation of the cytosolic tail by glycogen synthase kinase $3 \beta$ also inhibits its recycling from endosomes back to the plasma membrane [31]. Fast recycling requires rapid disruption of the megalin-ligand complex through acidification in endosomes, a process depending on voltage-gated chloride channel 5 (ClC-5) and vacuolar $\mathrm{H}^{+}$-ATPase. Their colocalization is believed to allow $\mathrm{ClC}-5$ to move in chloride as a counter-ion to the proton that is pumped by the vacuolar $\mathrm{H}^{+}$-ATPase $[32,33]$, thus ensuring optimal acidification.

\section{Genetic Mutations Affecting Megalin}

LRP2 mutations, as occurring in the Donnai-Barrow/FacioOculo-Acoustico-Renal syndrome, result in impaired megalin function. Patients display proteinuria [34], hypercalciuria, nephrocalcinosis, nephrolithiasis, and focal segmental glomerulosclerosis [35]. Genome-wide association studies confirmed the link between LRP2 and proteinuria [36]. Interestingly, patients with mutations in the genes encoding for OCRL1 (Lowe syndrome) and ClC-5 (Dent's disease) also display megalin dysfunction and proteinuria [37-39]. This can be explained based on the importance of OCRL 1 and ClC- 5 for megalin endocytosis and endosomal acidification, respectively (Fig. 1).

\section{Megalin and Kidney Disease}

Megalin knockout mice display increased albumin excretion [40] and are protected against kidney damage resulting from a high-fat diet [24]. Similar protective effects are derived from megalin inhibition (e.g., with cilastatin) in relationship to acute kidney injury due to the uptake of nephrotoxic drugs like vancomycin and cisplatin [41]. Anti-brush border antibody disease or anti-LRP2 nephropathy involves the deposit of large amounts of circulating IgG through megalin in the renal tubule. This might explain why autoantibodies induce acute kidney injury [42]. Excess albumin, as occurring in patients with chronic kidney disease (CKD), directly contributes to the development and progression of CKD by inducing tubulointerstitial inflammation and fibrosis in a megalindependent manner [43]. Urinary excretion of megalin associates with renal oxidative stress in CKD [44, 45], while megalin excretion in both urine and urinary extracellular vesicles correlates with the progression of albuminuria in type 2 diabetes mellitus [46, 47]. The latter implies that urinary megalin could be a biomarker for diabetic nephropathy. Yet, renal megalin expression is decreased in diabetes [13••], although increases have been observed in the early stage of type 2 diabetes $[48,49]$. Among the factors that lower megalin is Ang II [50]. 
Fig. 1 Megalin and its associated molecules in the proximal tubule. EGF, epidermal growth factor; OCRL1, oculocerebrorenal syndrome protein 1 ; ClC-5, voltage-gated chloride channel 5; ARH, autosomal recessive hypercholesterolemia; (P)RR, (pro)renin receptor; V-ATPase, vacuolar $\mathrm{H}^{+}$-ATPase; CUB, complement subcomponents $\mathrm{C} 1 \mathrm{r}$ and $\mathrm{C} 1 \mathrm{~s}$, fibropellin, and bone morphogenetic protein 1

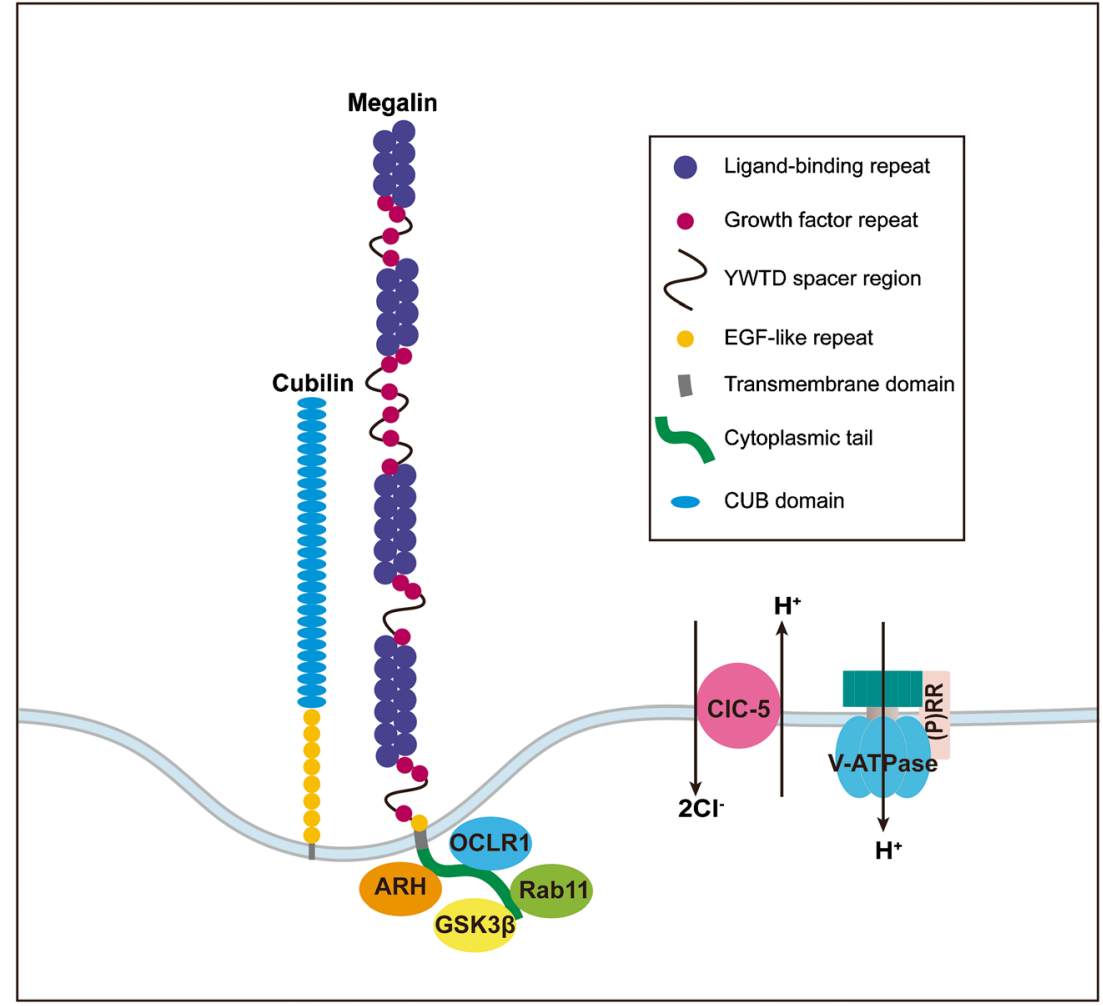

\section{Megalin and Urinary RAS Components}

Both renin and angiotensinogen can be detected in urine, albeit at very low levels (a few percent or less) when expressed as a percentage of their concomitant plasma concentrations $[12,51]$. Prorenin is undetectable in urine [12]. The latter is not due to prorenin-renin conversion in urine [12]. Remarkably, renin and angiotensinogen massively rise (up to 40-fold) in urine of patients with Dent's disease or Lowe syndrome [52], and the same occurs in urine of megalin knockdown mice [15•], or after megalin inhibition with lysine [53]. In fact, prorenin can also be detected in the urine of patients with Dent's disease or Lowe syndrome. From these data, it can be concluded that RAS components are present in the ultrafiltrate, but normally are largely $(>95 \%)$ reabsorbed in a megalin-dependent manner [15•, 52-54], and possibly near-completely in the case of prorenin. Indeed, all 3 RAS components are filtered through the glomerulus and colocalize with megalin in the kidney [49, 54]. In fact, since both renin and prorenin are smaller than albumin, relatively larger amounts of renin and prorenin will pass the glomerulus in comparison with albumin. Not surprisingly, the glomerular sieving coefficients of renin, prorenin, and angiotensinogen increase after damaging the glomerular filtration barrier [52], e.g., in diabetes. Moreover, in mice, the rise in urinary renin after lysine was smaller under diabetic conditions than under normal conditions $(\approx 10$-fold versus $\approx 100$-fold) [13••]. This is suggestive for disturbed tubular reabsorption. Therefore, the elevated urinary RAS component levels in diabetes do not reflect release from renal (tubular) tissue sites but are the consequence of enhanced filtration from blood plasma in combination with reduced reabsorption [13••]. One more condition where urinary renin, prorenin, and angiotensinogen levels are unexpectedly high is preeclampsia [55]. Like in diabetes, this may reflect enhanced filtration; to what degree megalin is downregulated in this condition is still unknown. It is also unknown whether megalin-dependent reabsorption is different for renin and prorenin.

\section{Megalin and Renal Angiotensin Production}

After establishing that renal angiotensin generation depends on liver-derived angiotensinogen, while renal angiotensinogen staining was limited to proximal tubule cells expressing megalin, Matsusaka and colleagues studied whether megalin is a determinant of angiotensin production at renal tissue sites [14*•]. It was observed that proximal tubule-specific knockout of megalin in mice did not affect renal Ang II levels, although such knockout did massively increase urinary angiotensinogen levels. Yet, when inducing podocyte injury with the immunotoxin LMB2, the well-known rise in renal angiotensinogen and Ang II levels no longer occurred without tubular megalin. As a consequence, the Ang II-mediated $\mathrm{Na}^{+}$ reabsorption via sodium-hydrogen exchanger 3 and the epithelial sodium channel were diminished, and thus the megalin knockout mice excreted 5 times more sodium after podocyte 
injury. In contrast with these findings, Ye et al. observed a profound (> 70\%) drop in renal Ang II levels in wild type mice after megalin suppression based on the application of megalin antisense oligonucleotides (ASO) [15•]. The ASO approach did not affect circulating Ang II and resulted in the expected huge increase in urinary renin and angiotensinogen. Yet, even more surprising, megalin ASO reduced the atherosclerotic lesions in LDLR KO mice fed a high-fat diet. This suggests that renal Ang II, generated in a megalin-dependent manner, contributes to atherosclerosis. However, an alternative explanation might be that the ASO approach additionally interfered with megalin at extrarenal sites (as opposed to the proximal tubule-specific knockout applied by Matsusaka et al. [14••]), and that this underlies the beneficial effect on atherosclerosis. Indeed, megalin has been reported to contribute to Ang II internalization and signaling $[50,56]$ and binds lipoproteins. Ideally therefore, these data are confirmed in the proximal tubule-specific knockout model. With regard to renal angiotensin generation, both studies imply that this is reduced without megalin, either selectively under pathological conditions (following podocyte injury) or possibly already under healthy conditions. Here it is important to note that we do not know the renal renin levels in these studies, and thus a final possibility is that megalin knockout has altered these levels (although it did not affect renin gene expression). In fact, under most circumstances, it is variation in renin and not variation in angiotensinogen, which underlies variations in renal angiotensin generation, and even an angiotensinogen suppression of $>95 \%$ can be matched by a rise in renin [7•]. Indeed, renin rises of $>100$-fold are easily achievable [57], and renal Ang II levels are unaltered when angiotensinogen is suppressed by $98 \%$ [7॰].

When proposing a role for megalin in renal angiotensin generation, the question is how exactly this might occur. Obviously, endocytosis should then not result in angiotensinogen destruction. According to Wilson et al. [58], internalized angiotensinogen traffics intact to the mitochondria in isolated proximal tubules. However, given the absence of intracellular angiotensin generation [4], the implications of this finding are unclear. An attractive hypothesis would be that angiotensinogen is transcytosed to the basolateral membrane and released into the renal interstitium (Fig. 2). Such megalin-dependent transcytosis has been observed for albumin in rats $[59,60]$ and even for angiotensinogen in opossum kidney cells [54]. Diffusion of hepatic angiotensinogen from the circulation into the interstitial space has been reported decades ago as the most important, if not only, source of tissue angiotensin production [61]. It seems unlikely that the minute amounts of angiotensinogen in the ultrafiltrate under healthy conditions would contribute significantly to the renal interstitial angiotensinogen levels. However, under conditions of excessive protein/ angiotensinogen leakage, assuming that megalin-mediated transcytosis takes place, it may indeed increase interstitial angiotensinogen and contribute to renal angiotensin production. In the case of prorenin, the acidic $\mathrm{pH}$ in the endosomes might even lead to prorenin activation, since a low $\mathrm{pH}$ results in non-proteolytic removal of the prosegment from the enzymatic cleft [62]. Yet, in previous studies, we were unable to
Fig. 2 Megalin-mediated endocytosis of prorenin, renin, and angiotensinogen, resulting in lysosomal degradation and/or transcytosis and subsequent release into the renal interstitium, allowing angiotensin generation. The low $\mathrm{pH}$ in endosomes may result in non-proteolytic prorenin activation (i.e., removal of the prosegment from the enzymatic cleft, resulting in "open," active prorenin)

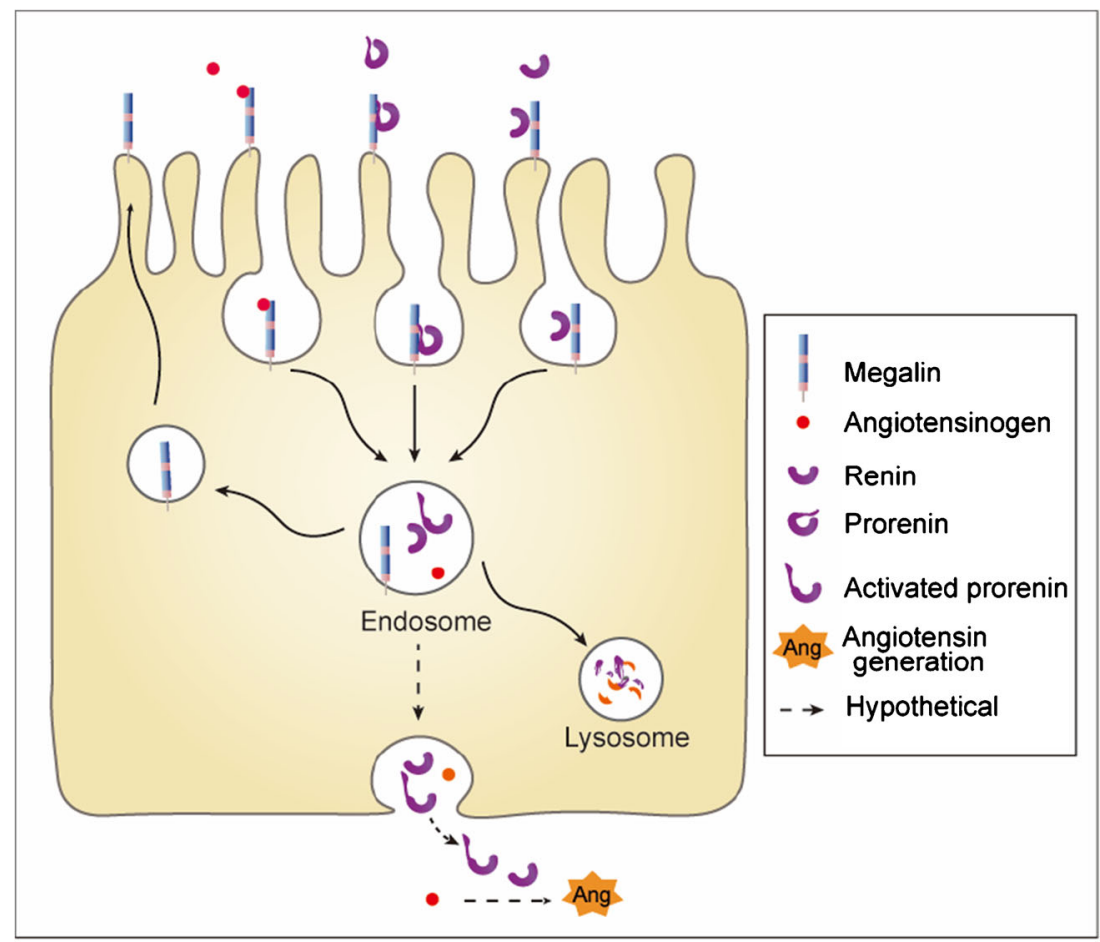


show release of activated prorenin from prorenin-synthesizing cells, possibly because activated prorenin rapidly returns to the non-activated state in a neutral $\mathrm{pH}$ environment [63].

\section{Megalin and the (Pro)Renin Receptor}

Numerous studies have investigated the so-called (pro)renin receptor as a novel component of the RAS over the last 2 decades. Although this receptor was initially reported to bind and activate prorenin [64], later studies revealed that the prorenin levels required to allow such interaction are many orders above its in vivo levels, even under pathological conditions [65, 66]. Hence, this concept is now being abandoned, also because it has become clear that the (pro)renin receptor is an accessory protein of vacuolar $\mathrm{H}^{+}$-ATPase (also known as ATP6AP2), and thus has important functions beyond the RAS, like facilitating vesicle trafficking, intracellular signaling, and lipid metabolism [67-70]. As such, it may also contribute to megalin sorting and recycling, since it determines endosomal acidification in concert with ClC-5 (Fig. 1). In agreement with this concept, ATP6AP2 inhibition impaired megalin protein regulation in Drosophila epithelial cells [71]. Thus, via megalin, the (pro)renin receptor may display a relationship with renin and prorenin.

\section{Conclusions and Remaining Questions}

Megalin is a multi-ligand receptor mainly (but not exclusively!) expressed in the kidney, determining protein reabsorption in the proximal tubule. Both genetic mutations and kidney disease (e.g., diabetes, preeclampsia) affect its function and expression, thus contributing to kidney pathology. Since megalin also binds RAS components, an intriguing new concept is that it might even play a role in angiotensin generation at renal tissue sites. If so, its internalization should not result in destruction, but, for instance, via transcytosis, result in angiotensinogen release into the renal interstitial space. Such release would obviously depend on the level of angiotensinogen in the ultrafiltrate (reflecting podocyte injury) and tubular megalin expression, thus explaining why renal angiotensin generation may not always occur in concert with angiotensin generation in the circulation. Furthermore, megalin determines the level of RAS components in urine, and in the absence of megalin (like in Dent's disease or Lowe syndrome), urinary renin and angiotensinogen levels can easily rise by 2 orders of magnitude [52]. As such, urinary renin and angiotensinogen components do not reflect release from renal tissue sites (like the collecting duct) but rather diminished uptake of filtered RAS components. Given the virtual absence of prorenin (despite its filtration) in urine, except under conditions where megalin function is disturbed, it seems that megalin prefers prorenin over renin. Future studies should now address this concept, e.g., making use of megalin- expressing cells like proximal tubule epithelial cells and Brown Norway Rat yolk sac epithelial cells. Such studies might also shed light on RAS component transcytosis. Additionally, in vivo renal angiotensin generation should be verified in the presence or absence of megalin and during inhibition of hepatic angiotensinogen synthesis, ruling out that alterations in renal renin levels and/or megalin-dependent signaling underlie the observed changes in kidney Ang II levels after megalin knockout $[14 \bullet \bullet, 15 \bullet]$. Knowledge on megalin expression in preeclampsia might shed light on the occurrence of prorenin in urine of women with preeclampsia [55]. Finally, we need to know what determines renin uptake in the collecting duct, reported recently by Tang et al. [13・•], given that megalin is unlikely to occur in significant amounts at this location. Here, the link between megalin and the (pro)renin receptor may be of particular interest.

Acknowledgments This work was supported by National Natural Science Foundation of China (grant no. 81800383 and 81870605), Shenzhen Key Laboratory of Metabolism and Cardiovascular Homeostasis, and Shenzhen Municipal Science and Technology Innovation Council (grant no. JCYJ20160307160819191).

\section{Compliance with Ethical Standards}

Conflict of Interest The authors declare no conflicts of interest relevant to this manuscript.

Human and Animal Rights and Informed Consent This article does not contain any studies with human or animal subjects performed by any of the authors.

Open Access This article is licensed under a Creative Commons Attribution 4.0 International License, which permits use, sharing, adaptation, distribution and reproduction in any medium or format, as long as you give appropriate credit to the original author(s) and the source, provide a link to the Creative Commons licence, and indicate if changes were made. The images or other third party material in this article are included in the article's Creative Commons licence, unless indicated otherwise in a credit line to the material. If material is not included in the article's Creative Commons licence and your intended use is not permitted by statutory regulation or exceeds the permitted use, you will need to obtain permission directly from the copyright holder. To view a copy of this licence, visit http://creativecommons.org/licenses/by/4.0/.

\section{References}

Papers of particular interest, published recently, have been highlighted as:

- Of importance

•- Of major importance

1. van Kats JP, Schalekamp MADH, Verdouw PD, Duncker DJ, Danser AHJ. Intrarenal angiotensin II: interstitial and cellular levels and site of production. Kidney Int. 2001;60:2311-7. 
2. Campbell DJ, Duncan AM, Kladis A. Angiotensin-converting enzyme inhibition modifies angiotensin but not kinin peptide levels in human atrial tissue. Hypertension. 1999;34:171-5.

3. van Kats JP, van Meegen JR, Verdouw PD, Duncker DJ, Schalekamp MADH, Danser AHJ. Subcellular localization of angiotensin II in kidney and adrenal. J Hypertens. 2001;19:583-9.

4. van Esch JHM, Gembardt F, Sterner-Kock A, Heringer-Walther S, Le T, Lassner D, et al. Cardiac phenotype and angiotensin II levels in AT1a, AT1b and AT2 receptor single, double and triple knockouts. Cardiovasc Res. 2010;86:401-9.

5. Matsusaka T, Niimura F, Pastan I, Shintani A, Nishiyama A, Ichikawa I. Podocyte injury enhances filtration of liver-derived angiotensinogen and renal angiotensin II generation. Kidney Int. 2014;85:1068-77.

6. Matsusaka T, Niimura F, Shimizu A, Pastan I, Saito A, Kobori H, et al. Liver angiotensinogen is the primary source of renal angiotensin II. J Am Soc Nephrol. 2012;23:1181-9.

7. Uijl E, Mirabito Colafella KM, Sun Y, Ren L, van Veghel R, Garrelds IM, et al. Strong and sustained antihypertensive effect of small interfering RNA targeting liver angiotensinogen. Hypertension. 2019;73:1249-57 This study reports on the consequences of hepatic angiotensinogen deletion on renal angiotensin II levels.

8. Arendse LB, Danser AHJ, Poglitsch M, Touyz RM, Burnett JC Jr, Llorens-Cortes $\mathrm{C}$, et al. Novel therapeutic approaches targeting the renin-angiotensin system and associated peptides in hypertension and heart failure. Pharmacol Rev. 2019;71:539-70.

9. Hollenberg NK, Fisher ND, Nussberger J, Moukarbel GV, Barkoudah E, Danser AHJ. Renal responses to three types of renin-angiotensin system blockers in patients with diabetes mellitus on a high-salt diet: a need for higher doses in diabetic patients? J Hypertens. 2011;29:2454-61.

10. Kang JJ, Toma I, Sipos A, Meer EJ, Vargas SL, Peti-Peterdi J. The collecting duct is the major source of prorenin in diabetes. Hypertension. 2008;51:1597-604.

11. Persson F, Lu X, Rossing P, Garrelds IM, Danser AHJ, Parving HH. Urinary renin and angiotensinogen in type 2 diabetes: added value beyond urinary albumin? J Hypertens. 2013;31:1646-52.

12. van den Heuvel M, Batenburg WW, Jainandunsing S, Garrelds IM, van Gool JM, Feelders RA, et al. Urinary renin, but not angiotensinogen or aldosterone, reflects the renal reninangiotensin-aldosterone system activity and the efficacy of reninangiotensin-aldosterone system blockade in the kidney. $\mathrm{J}$ Hypertens. 2011;29:2147-55.

13.• Tang J, Wysocki J, Ye M, Vallés PG, Rein J, Shirazi M, et al. Urinary renin in patients with diabetic kidney disease. Hypertension. 2019;74:83-94 This study shows that urinary renin in diabetes is filtered from plasma, and that there is no release of renin from the collecting duct.

14.• Koizumi M, Ueda K, Niimura F, Nishiyama A, Yanagita M, Saito A, et al. Podocyte injury augments intrarenal angiotensin II generation and sodium retention in a megalin-dependent manner. Hypertension. 2019;74:509-17 This study elegantly unravels the role of megalin for renal angiotensin generation under normal and pathological conditions.

15. Ye F, Wang Y, Wu C, Howatt DA, Wu CH, Balakrishnan A, et al. Angiotensinogen and megalin interactions contribute to atherosclerosis. Arterioscler Thromb Vasc Biol. 2019;39:150-5 This study reports the unexpected view that atherosclerosis depends on renal angiotensin generated in a megalin-dependent manner.

16. Kerjaschki D, Farquhar MG. The pathogenic antigen of Heymann nephritis is a membrane glycoprotein of the renal proximal tubule brush border. Proc Natl Acad Sci U S A. 1982;79:5557-61.

17. Saito A, Pietromonaco S, Loo AK, Farquhar MG. Complete cloning and sequencing of rat gp330/“megalin," a distinctive member of the low density lipoprotein receptor gene family. Proc Natl Acad Sci U S A. 1994;91:9725-9.

18. Nielsen R, Christensen EI, Birn H. Megalin and cubilin in proximal tubule protein reabsorption: from experimental models to human disease. Kidney Int. 2016;89:58-67.

19. De S, Kuwahara S, Saito A. The endocytic receptor megalin and its associated proteins in proximal tubule epithelial cells. Membranes (Basel). 2014;4:333-55.

20. Cui S, Verroust PJ, Moestrup SK, Christensen EI. Megalin/gp330 mediates uptake of albumin in renal proximal tubule. Am J Phys. 1996;271:F900-7.

21. Willnow TE, Christ A. Endocytic receptor LRP2/megalin-of holoprosencephaly and renal Fanconi syndrome. Pflugers Arch. 2017;469:907-16.

22. Christensen EI, Birn H. Megalin and cubilin: multifunctional endocytic receptors. Nat Rev Mol Cell Biol. 2002;3:256-66.

23. Christensen EI, Nielsen S, Moestrup SK, Borre C, Maunsbach AB, de Heer E, et al. Segmental distribution of the endocytosis receptor gp330 in renal proximal tubules. Eur J Cell Biol. 1995;66:349-64.

24. Kukida M, Sawada H, Daugherty A, Lu HS. Megalin: a bridge connecting kidney, the renin-angiotensin system, and atherosclerosis. Pharmacol Res. 2019;151:104537.

25. Le Panse S, Ayani E, Nielsen S, Ronco P, Verroust P, Christensen EI. Internalization and recycling of glycoprotein 280 in epithelial cells of yolk sac. Eur J Cell Biol. 1997;72:257-67.

26. Chatelet F, Brianti E, Ronco P, Roland J, Verroust P. Ultrastructural localization by monoclonal antibodies of brush border antigens expressed by glomeruli. I Renal distribution Am J Pathol. 1986;122:500-11.

27. Oltrabella F, Pietka G, Ramirez IB, Mironov A, Starborg T, Drummond IA, et al. The Lowe syndrome protein OCRL1 is required for endocytosis in the zebrafish pronephric tubule. PLoS Genet. 2015;11:e1005058.

28. Marzolo MP, Farfan P. New insights into the roles of megalin/LRP2 and the regulation of its functional expression. Biol Res. 2011;44: 89-105.

29. Perez Bay AE, Schreiner R, Benedicto I, Paz Marzolo M, Banfelder $\mathrm{J}$, Weinstein AM, et al. The fast-recycling receptor megalin defines the apical recycling pathway of epithelial cells. Nat Commun. 2016;7:11550.

30. Shah M, Baterina OY Jr, Taupin V, Farquhar MG. ARH directs megalin to the endocytic recycling compartment to regulate its proteolysis and gene expression. J Cell Biol. 2013;202:113-27.

31. Yuseff MI, Farfan P, Bu G, Marzolo MP. A cytoplasmic PPPSP motif determines megalin's phosphorylation and regulates receptor's recycling and surface expression. Traffic. 2007;8:1215-30.

32. Lin Z, Jin S, Duan X, Wang T, Martini S, Hulamm P, et al. Chloride channel $(\mathrm{Clc})-5$ is necessary for exocytic trafficking of $\mathrm{Na}+\mathrm{H}+$ exchanger 3 (NHE3). J Biol Chem. 2011;286:22833-45.

33. Hryciw DH, Jenkin KA, Simcocks AC, Grinfeld E, McAinch AJ, Poronnik P. The interaction between megalin and $\mathrm{ClC}-5$ is scaffolded by the $\mathrm{Na}(+)-\mathrm{H}(+)$ exchanger regulatory factor 2 (NHERF2) in proximal tubule cells. Int J Biochem Cell Biol. 2012;44:815-23.

34. Ozdemir H, Plamondon J, Gaskin P, Asoglu MR, Turan S. A prenatally diagnosed case of Donnai-Barrow syndrome: highlighting the importance of whole exome sequencing in cases of consanguinity. Am J Med Genet A. 2020;182:289-92.

35. Longoni M, Kantarci S, Donnai D, Pober BR. In: Adam MP, Ardinger HH, Pagon RA, Wallace SE, LJH B, Stephens K, et al., editors. Donnai-Barrow syndrome. Seattle: GeneReviews((R)); 1993.

36. Benonisdottir S, Kristjansson RP, Oddsson A, Steinthorsdottir V, Mikaelsdottir E, Kehr B, et al. Sequence variants associating with urinary biomarkers. Hum Mol Genet. 2019;28:1199-211. 
37. Eshbach ML, Weisz OA. Receptor-mediated endocytosis in the proximal tubule. Annu Rev Physiol. 2017;79:425-48.

38. De Matteis MA, Staiano L, Emma F, Devuyst O. The 5phosphatase OCRL in Lowe syndrome and dent disease 2. Nat Rev Nephrol. 2017;13:455-70.

39. Christensen EI, Devuyst O, Dom G, Nielsen R, Van der Smissen P, Verroust P, et al. Loss of chloride channel ClC-5 impairs endocytosis by defective trafficking of megalin and cubilin in kidney proximal tubules. Proc Natl Acad Sci U S A. 2003;100:8472-7.

40. Weyer K, Storm T, Shan J, Vainio S, Kozyraki R, Verroust PJ, et al. Mouse model of proximal tubule endocytic dysfunction. Nephrol Dial Transplant. 2011;26:3446-51.

41. Hori Y, Aoki N, Kuwahara S, Hosojima M, Kaseda R, Goto S, et al. Megalin blockade with cilastatin suppresses drug-induced nephrotoxicity. J Am Soc Nephrol. 2017;28:1783-91.

42. Larsen CP, Trivin-Avillach C, Coles P, Collins AB, Merchant M, $\mathrm{Ma} \mathrm{H}$, et al. LDL receptor-related protein 2 (Megalin) as a target antigen in human kidney anti-brush border antibody disease. J Am Soc Nephrol. 2018;29:644-53.

43. Liu D, Wen Y, Tang TT, Lv LL, Tang RN, Liu H, et al. Megalin/ cubulin-lysosome-mediated albumin reabsorption is involved in the tubular cell activation of NLRP3 inflammasome and tubulointerstitial inflammation. J Biol Chem. 2015;290:18018-28.

44. Nakatani S, Nakatani A, Ishimura E, Toi N, Tsuda A, Mori K, et al. Urinary iron excretion is associated with urinary full-length megalin and renal oxidative stress in chronic kidney disease. Kidney Blood Press Res. 2018;43:458-70.

45. Toi N, Inaba M, Ishimura E, Tsugawa N, Imanishi Y, Emoto M, et al. Significance of urinary C-megalin excretion in vitamin D metabolism in pre-dialysis CKD patients. Sci Rep. 2019;9:2207.

46. De S, Kuwahara S, Hosojima M, Ishikawa T, Kaseda R, Sarkar P, et al. Exocytosis-mediated urinary full-length megalin excretion is linked with the pathogenesis of diabetic nephropathy. Diabetes. 2017;66:1391-404.

47. Akour A, Kasabri V, Bulatova N, Al-Motassem Y, Fahmawi H, Momani M, et al. Urinary megalin in association with progression factors of diabetic nephropathy. Bratisl Lek Listy. 2019;120:532-5.

48. Bryniarski MA, Yee BM, Jaffri I, Chaves LD, Yu JA, Guan X, et al. Increased megalin expression in early type 2 diabetes: role of insulin-signaling pathways. Am J Physiol Renal Physiol. 2018:315:F1191-F207.

49. Tojo A, Kinugasa S, Fujita T, Wilcox CS. A local renal reninangiotensin system activation via renal uptake of prorenin and angiotensinogen in diabetic rats. Diabetes Metab Syndr Obes. 2016;9:1-10

50. Li XC, Zhuo JL. Mechanisms of AT1a receptor-mediated uptake of angiotensin II by proximal tubule cells: a novel role of the multiligand endocytic receptor megalin. Am J Physiol Renal Physiol. 2014;307:F222-33.

51. Lumbers ER, Skinner SL. Observations on the origin of renin in human urine. Circ Res. 1969;24:689-97.

52. Roksnoer LCW, Heijnen BF, Nakano D, Peti-Peterdi J, Walsh SB, Garrelds IM, et al. On the origin of urinary renin: a translational approach. Hypertension. 2016;67:927-33.

53. Mazanti I, Hermann KL, Nielsen AH, Poulsen K. Ultrafiltration of renin in the mouse kidney studied by inhibition of tubular protein reabsorption with lysine. Clin Sci (Lond). 1988;75:331-6.

54. Pohl M, Kaminski H, Castrop H, Bader M, Himmerkus N, Bleich $\mathrm{M}$, et al. Intrarenal renin angiotensin system revisited: role of megalin-dependent endocytosis along the proximal nephron. J Biol Chem. 2010;285:41935-46.

55. Verdonk K, Saleh L, Lankhorst S, Smilde JEI, van Ingen MM, Garrelds IM, et al. Association studies suggest a key role for endothelin-1 in the pathogenesis of preeclampsia and the accompanying renin-angiotensin-aldosterone system suppression. Hypertension. 2015;65:1316-23.

56. Gonzalez-Villalobos R, Klassen RB, Allen PL, Navar LG, Hammond TG. Megalin binds and internalizes angiotensin II. Am J Physiol Renal Physiol. 2005;288:F420-7.

57. Balcarek J, Sevá Pessôa B, Bryson C, Azizi M, Ménard J, Garrelds IM, et al. Multiple ascending dose study with the new renin inhibitor VTP-27999: nephrocentric consequences of too much renin inhibition. Hypertension. 2014;63:942-50.

58. Wilson BA, Cruz-Diaz N, Su Y, Rose JC, Gwathmey TM, Chappell MC. Angiotensinogen import in isolated proximal tubules: evidence for mitochondrial trafficking and uptake. Am J Physiol Renal Physiol. 2017;312:F879-F86.

59. Sandoval RM, Wagner MC, Patel M, Campos-Bilderback SB, Rhodes GJ, Wang E, et al. Multiple factors influence glomerular albumin permeability in rats. J Am Soc Nephrol. 2012;23:447-57.

60. Russo LM, Sandoval RM, McKee M, Osicka TM, Collins AB, Brown D, et al. The normal kidney filters nephrotic levels of albumin retrieved by proximal tubule cells: retrieval is disrupted in nephrotic states. Kidney Int. 2007;71:504-13.

61. de Lannoy LM, Danser AHJ, van Kats JP, Schoemaker RG, Saxena PR, Schalekamp MADH. Renin-angiotensin system components in the interstitial fluid of the isolated perfused rat heart. Local production of angiotensin I. Hypertension. 1997;29:1240-51.

62. Schalekamp MADH, Derkx FHM, Deinum J, Danser AHJ. Newly developed renin and prorenin assays and the clinical evaluation of renin inhibitors. J Hypertens. 2008;26:928-37.

63. Martini AG, Krop M, Saleh L, Garrelds IM, Danser AH. Do prorenin-synthesizing cells release active, 'open' prorenin? J Hypertens. 2017;35:330-7.

64. Nguyen G, Delarue F, Burcklé C, Bouzhir L, Giller T, Sraer J-D. Pivotal role of the renin/prorenin receptor in angiotensin II production and cellular responses to renin. J Clin Invest. 2002;109:141727.

65. Batenburg WW, Danser AHJ. (Pro)renin and its receptors: pathophysiological implications. Clin Sci (Lond). 2012;123:121-33.

66. Batenburg WW, Lu X, Leijten F, Maschke U, Müller DN, Danser AHJ. Renin- and prorenin-induced effects in rat vascular smooth muscle cells overexpressing the human (pro)renin receptor: does (pro)renin-(pro)renin receptor interaction actually occur? Hypertension. 2011;58:1111-9.

67. Sun Y, Danser AHJ, Lu X. (Pro)renin receptor as a therapeutic target for the treatment of cardiovascular diseases? Pharmacol Res. 2017;125:48-56.

68. Ramkumar N, Kohan DE. The (pro)renin receptor: an emerging player in hypertension and metabolic syndrome. Kidney Int. 2019;95:1041-52.

69. Ren L, Sun Y, Lu H, Ye D, Han L, Wang N, et al. (Pro)renin receptor inhibition reprograms hepatic lipid metabolism and protects mice from diet-induced obesity and hepatosteatosis. Circ Res. 2018;122:730-41

70. Lu X, Meima ME, Nelson JK, Sorrentino V, Loregger A, Scheij S, et al. Identification of the (pro)renin receptor as a novel regulator of low-density lipoprotein metabolism. Circ Res. 2016;118:222-9.

71. Gleixner EM, Canaud G, Hermle T, Guida MC, Kretz O, Helmstadter M, et al. V-ATPase/mTOR signaling regulates megalin-mediated apical endocytosis. Cell Rep. 2014;8:10-9.

Publisher's Note Springer Nature remains neutral with regard to jurisdictional claims in published maps and institutional affiliations. 